\title{
THE IMPACT OF LEARNING CULTURAL HISTORY OF ISLAM USING VIDEO MEDIA ON SPIRITUAL STUDENTS: A STUDY OF UMAR BIN ABDUL AZIZ
}

\author{
Bashir $^{1 *}$, Joko Nurkamto ${ }^{2}$, M. Furqan Hidayatullah ${ }^{3}$, Asrowi $^{4}$ \\ ${ }^{1}$ Student of Doctoral Program of Science Education, Universitas Sebelas Maret, Surakarta, Indonesia; ${ }^{2,3,4}$ Lecturers of \\ Faculty of Education and Teacher Training, Universitas Sebelas Maret, Surakarta, Indonesia. \\ Email: ${ }^{1 *}$ basstk71@gmail.com, ${ }^{2}$ jokonurkamto@ gmail.com, ${ }^{3}$ furqon@ fkip.uns.ac.id, ${ }^{4}$ asrowi@ staff.uns.ac.id \\ Article History: Received on $24^{\text {th }}$ March 2020, Revised on $24^{\text {th }}$ April 2020, Published on $16^{\text {th }}$ May 2020
}

\begin{abstract}
Purpose of the study: The purpose of this study was to determine the impact of learning the history of Islamic culture using Video Media on the spirit of students. Spiritual students in the story of Umar bin Abdul Aziz in terms of Umar bin Abdul Aziz's achievements and lessons (ibrah).
\end{abstract}

Methodology: The research method used was pedagogical action research, data obtained from students' questionnaires, then analyzed descriptively qualitatively. The sample involved in learning consisted of 2811 th grade students in one of the Aliyah Madrasahs in Sukoharjo district, Central Java, Indonesia.

Main Findings: The results showed that the impact of learning the history of Islamic culture using video on the spiritual of students was categorized very well, this was based on four main themes, namely the idea of God, leadership, social, and nature.

Application of this study: While the average percentage of student responses on the ability to pick In from the highest is, the theme of nature or example is $99.11 \%$, the theme of God is $97.62 \%$, the social theme is $96.43 \%$, and the theme of Leadership is $95.24 \%$. Based on these results, video technology provides an effective impact on learning.

Novelty/Originality of this study: Novelty the learning media of the history of Islamic culture, using animated videos. Cultural history is made in the form history of Umar bin Abdul Aziz.

Keywords: Spiritual, Islamic Cultural History, Spiritual Reflection, Video-Based Learning, Learning Impact, Achievement.

\section{INTRODUCTION}

The challenges of 21st-century education today include equipping students the ability to develop their spiritual potential as part of the life skills that students must have, namely: i) Digital age literacy; ii) Inventive thinking; iii) Effective communication; iv) High productivity; and iv) Spiritual values (Arsad, Osman, \& Soh, 2011; Kemendikbud, 2017; Soh, Osman, \& Arsad, 2012) so that in learning, teachers must develop the potential of participants, among these spiritual forms is the ability to make sense of subject matter that has been determined in the curriculum (Buchanan \& Hyde, 2008; Seifert, Goodman, \& Harmon, 2009).

Indonesian National Education System Law No. 20 of 2013 mandates the existence of education that develops student spirituality, including the development of student spirituality in classroom learning in Islamic Cultural History (in Indonesia called Sejarah Kebudayaan Islam, SKI) subjects; teachers must incorporate spiritual values into their teaching. Students are developed in their ability to live and practice the lessons they hold. Spiritual integration in learning still experiences many obstacles (Mthembu, Wegner, \& Roman, 2017), for example, obstacles in applying technology in combination with learning in the class (Bingimals, 2009).

The use of instructional videos related to curriculum material can be one of the solutions as learning tools/media that strengthen the spirit of students supported by research from (Misztal, Gurba, \& Nęcek, 2018; Mokhtar, 2017)in the form of techno-religious or also from (Spyker, 2007) that technology has an effect on the spiritual life because the video has the potential to create a real impact on education (Tsur, 2014).

\section{LITERATURE REVIEW}

Historical video literacy empowers students to realize, describe, and analyze the purpose of the film being made. The theme of the film raised is a good source of learning in history lessons; films can visualize past events (Marcus, Metzger, Paxton, \& Stoddard, 2018). Teachers have a lot of variation in the delivery of learning that is full of various innovations (for example, learning changes with videos ranging from video formats with CD (Compact Disk) video clips to interactive videos. In Video-based learning - YouTube provides broad opportunities in choosing educational videos that can improve and sharpening students' understanding of a learning topic (Khine \& Fisher, 2003; Mokhtar, 2017), Subject matter 
learning with spiritual cultivation can be done by teaching through video media (Graham, 2003).

Teaching history with video/film needs to pay attention to the following things: first, relating to students, the teacher shows that historical videos function the same as learning resources for books, or other written subscriptions. Schools develop media literacy, so students have better analytical skills (Fuller, 1999). This can, by understanding students can access the video as a source that can be used in order to understand different things and produce meaningful solutions to various problems (Ruismäki, Salomaa, \& Ruokonen, 2015). Second, with regard to teachers, the ability of teachers to prepare subject matter supported by video technology is the main key to the success of improvement and change in SKI education (Ruismäki et al., 2015). Teachers must also understand video technology in designing a video-based learning atmosphere in accordance with the learning objectives and support students in achieving those learning goals(Teuten et al., 2009).

\section{NEED OF THE STUDY AND OBJECTIVES}

Therefore, we need a study of the impact of learning the history of Islamic culture using video learning, on the spirit of students. It aims to find out how the spiritual description of students who take SKI learning with videos that are designed involves spiritually in SKI learning. How do students understand the narratives of the video story of Umar Bin Abdul Azis in a spiritual perspective by utilizing the knowledge they already have and with the help of their visual and audio power to explore the values of their connection with their divinity, their attributes, and the interrelationship of actions with values the divine value.

\section{METHOD}

\section{Research Design}

This study uses pedagogical action research (O’Siochru, 2019), in the type of thematic analysis, which is intended to look for patterns (patterns) of a theme under study. The research instrument uses an open questionnaire so that the patterns of the theme's findings become more specific. This research was conducted on the study of cultural history in the material achievement of Umar Bin Abdul Azis.

\section{Research Sample}

The sample involved in learning consisted of $2811^{\text {th }}$ grade students in one of the MadrasahAliyah (MA) in Sukoharjo district, Central Java, Indonesia. The sample with details of 10 female students and 18 male students. The sampling technique used is total sampling where it involves all the entire population to be examined as they have a particular set of characteristics. In selecting the sample here it applies a baseline which specific traits and knowledge. The chosen total sample must have been Islam by faith and familiar with Umar Bin Abdul Azi's story.

\section{Data Analysis}

Data obtained from students' responses in the form of students' written documents from their exploration of understanding their spirituality in interpreting the video material of Umar bin Abdul Azis' achievements in the form of video shows, the data obtained were then analyzed descriptively qualitatively to look for patterns/patterns of the proposed research problems. The questions used were two items. First, write down the observations of the video about the achievements of the Umayyad Dynasty during the period of Umar bin Abdul Aziz at least five achievements. Second, write down the results of reflection in the form of ibrah (lessons) obtained from video shows about the achievements of the Umayyad period Dynasty Umar bin Abdul Aziz at least three ibrah (lessons).

\section{RESULT}

To explore the content of video material, students pay attention to video shows, prepare themselves to record in their memory learning materials, and record messages from video content as a demonstration of their understanding. After finishing watching the video, the students are given a short time to reflect on their observations, then write down the results of their reflections to show understanding of the video shows they see.

In general, student responses to achievement and reflection in the form of ibrah consist of various reactions. We then categorize the responses into four main themes, namely the theme of God, leadership, social, and nature. The findings of the four themes are presented in Table 1.

Table 1: Findings of Learning Themes Based on Students' Responses

\begin{tabular}{lll}
\hline No & Themes & Category \\
\hline 1 & Allah & - Very afraid of $(a d z a b)$ Allah and his wrath. \\
& & - Always remember God \\
& & - A leader who obeys God \\
& & - Give yourself about everything to God \\
\hline 2. & Leadership & - The leader is a disaster \\
\hline
\end{tabular}




\begin{tabular}{|c|c|c|}
\hline No & Themes & Category \\
\hline & & $\begin{array}{l}\text { - Leaders to emulate } \\
\text { - Leaders who are very concerned and sensitive to the welfare and } \\
\text { prosperity of the people }\end{array}$ \\
\hline & Social & $\begin{array}{l}\text { - Concern for people who are wronged } \\
\text { - The leader is close to the people } \\
\text { - Willing to sacrifice for the people }\end{array}$ \\
\hline & Character & $\begin{array}{l}\text { - simple } \\
\text { - Fair } \\
\text { - Assertive } \\
\text { - Have strong and firm intentions } \\
\text { - wise } \\
\text { - discipline } \\
\text { - bravery } \\
\text { - trustful } \\
\text { - kind-hearted }\end{array}$ \\
\hline
\end{tabular}

Source: (Data Process Results, 2019).

These findings indicate that students have been able to respond to the form of achievements and lessons obtained from instructional video media in the achievement material Umar Bin Abdul Azis. In learning SKI, spiritual Islam means transcending SKI learning materials towards the things behind the subject matter to lead to self-awareness about the form of God and all His attributes and asthma, which means of subject matter related to the purpose of life seeking the pleasure of Allah. This can be done by writing a reflection of the subject matter learned in the classroom.

The theme of God is based on the students' response sentences, "Umar bin Abdul Aziz is a servant who fears Allah when he becomes a ruler". Or the answers of other similar students, for example, "are very afraid of God's punishment and His wrath". So the keywords fear are grouped in the theme of God. Besides, for example, student answers that say:

"(Umar bin Abdul Azis) a leader who is obedient to God",

or other student answers that state:

"(Umar bin Abdul Azis) always remember God",

these two student answers are also grouped into the theme of Allah with the key to remember and obey God.

Words that are the key to spiritual leadership are grouped into leadership themes, for example, students' answers that state, "leadership (power) is a disaster", or other students who explain that, "(Umar bin Abdul Azis) Leaders who can be emulated". The main keywords of disaster, caring, and sensitive are keywords to group into the theme of leadership because these words are directly related to leadership.

The theme of the social community, as the third theme of the findings of this study, is a reflection of students related to spirituality in social issues. For example, about keywords from students, caring for people who are wronged, close to the people, caring, and willing to sacrifice for the people (not personal). All of these can be included in social themes. The last theme is attributed (traits/traits), keywords that can be grouped in this theme come from students' explanations about the quality of spiritual qualities as a form of God's nature, or qualities that must be avoided because they conflict with spirituality.

Student Response To the Achievements of the Umayyad Dynasty during the period of Umar bin Abdul Aziz

Students' responses after seeing the video show, then write the observations of the video show about the achievements of the Umayyad Dynasty during the period of Umar bin Abdul Aziz at least five achievements. The overall response of students, presented in Figure 1.

Based on Figure 1 shows that the achievements of the Umayyad dynasty at the time of Umar bin Abdul Aziz there were four main themes, namely the theme of God, leadership, social community, and nature. Student responses about achievement on the theme of God, namely Give yourself about everything to God, and A leader who obeys God. The theme of leadership is A model leader, and Caring for People's Welfare. Universal themes are Leaders are close to the people, and Willing to sacrifice for the people. And on the theme of the nature or example of Umar bin Abdul Aziz namely Fair, Assertive, and Wise.

The mean percentage of student responses on each theme of the highest is, God's theme is $98.21 \%$ (27.5), Social theme is $98.21 \%$ (27.5), nature or exemplary theme is $96.53 \%$ (27), and the theme of Leadership was 91.07\% (25.5). One example of the response from students to the achievements of the Umayyad Dynasty during Umar bin Abdul Aziz is presented in 
Figure 2.

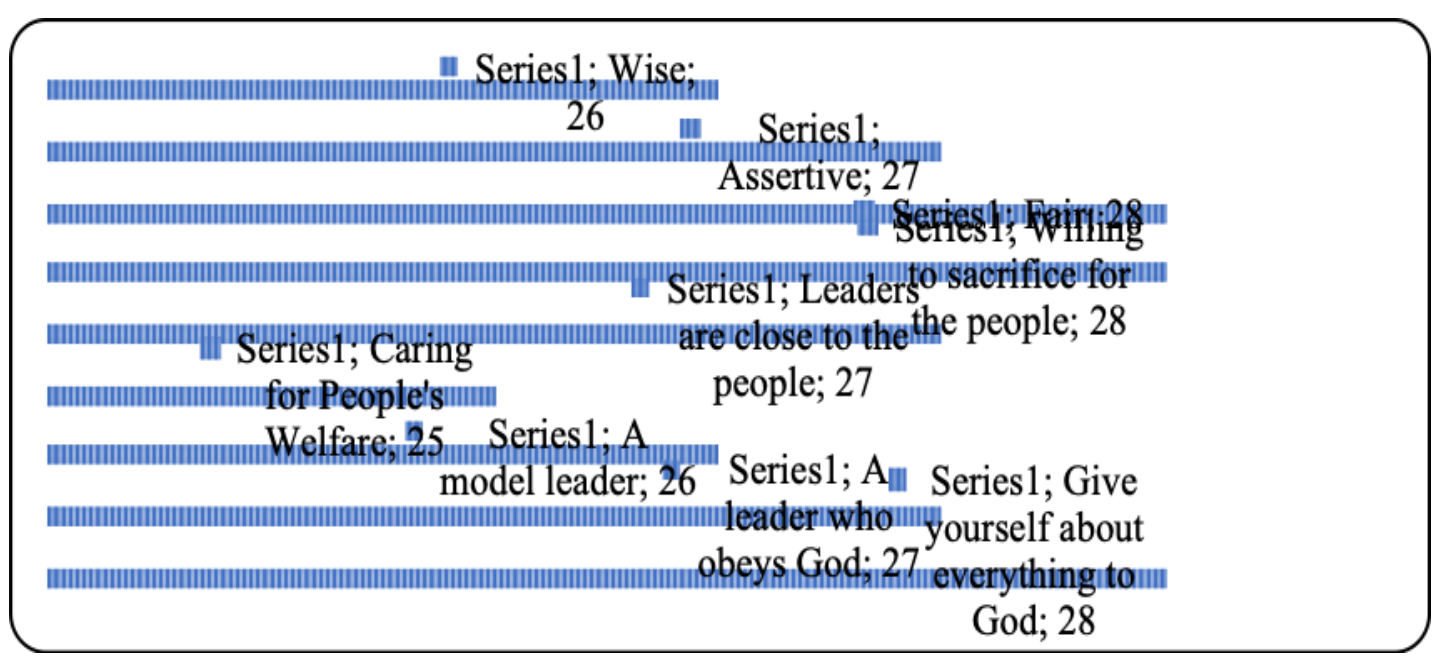

Figure 1: Student Achievement Response Umayyad Umar bin Abdul Aziz Era

Source: (Data Process Results, 2019)

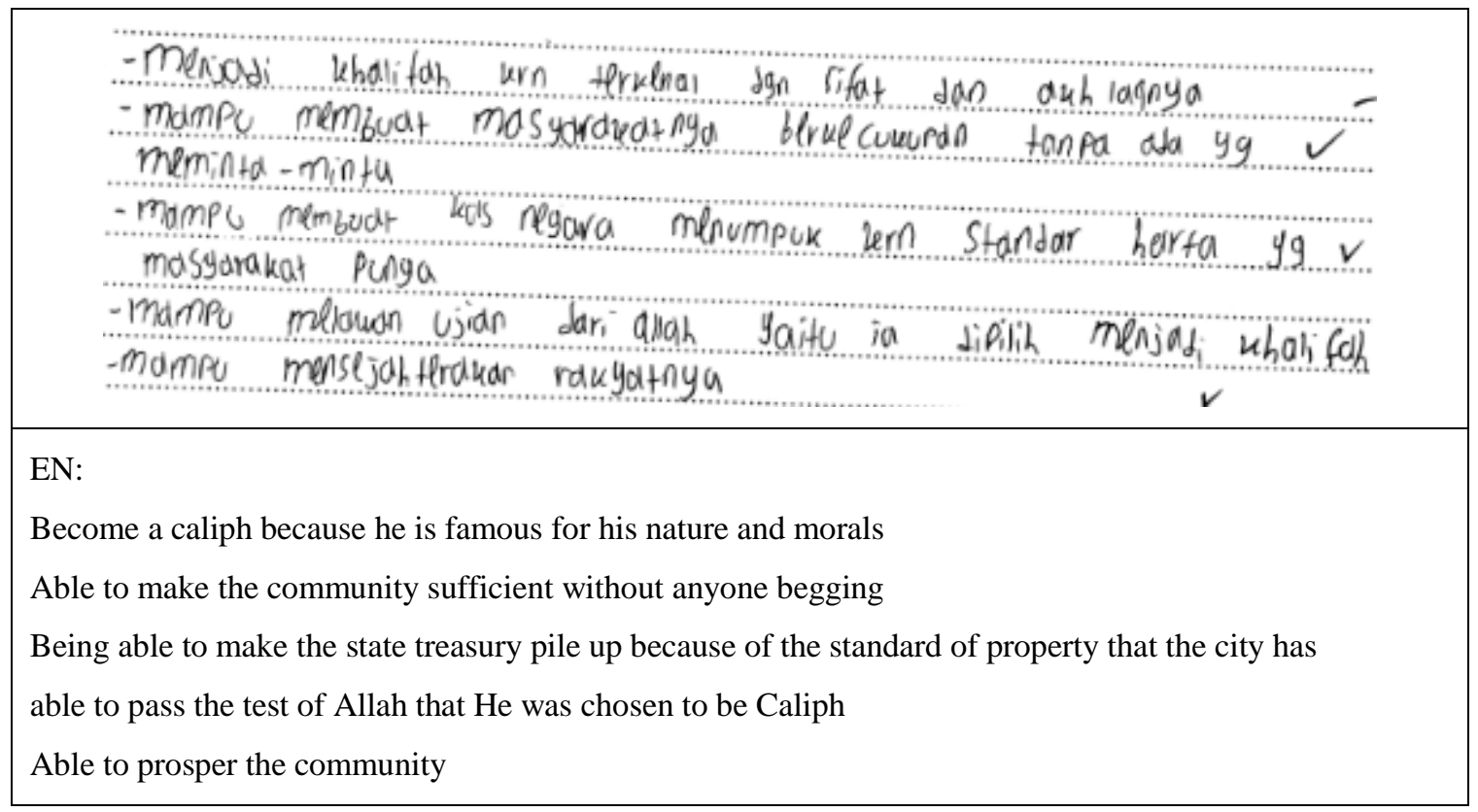

Figure 2: Examples of Student Responses to Umayyad Umar bin Abdul Aziz Achievements

Source: (Data Process Results, 2019)

The results of students' responses in Figure 2 show that one theme with another theme is interrelated, for example, the theme of God, including: "able to pass the test of God that he was chosen to be a caliph" Having a connection with the leadership theme of the category "responsibility for the mandate of leadership" which will be held accountable in the hereafter so that if it does not carry out the mandate properly the leadership mandate is seen as a disaster.

Extracts of Ibrah (Lesson) Achievements of the Umayyad Dynasty during the time of Umar bin Abdul Aziz

Students' responses after seeing the video show, then write down the observations of the video show about the passage of Ibn Umayyad's Umar bin Abdul Aziz's achievement at least three achievements. The overall response of students, presented in Figure 3.

Based on Figure 3 shows that the achievements of the Umayyad dynasty at the time of Umar bin Abdul Aziz there were four main themes, namely the theme of God, leadership, social community, and nature. Student responses regarding achievement on the theme of God are Very afraid of ( $a d z a b)$ Allah and his wrath, Always remember God, and Give yourself about everything to God. 


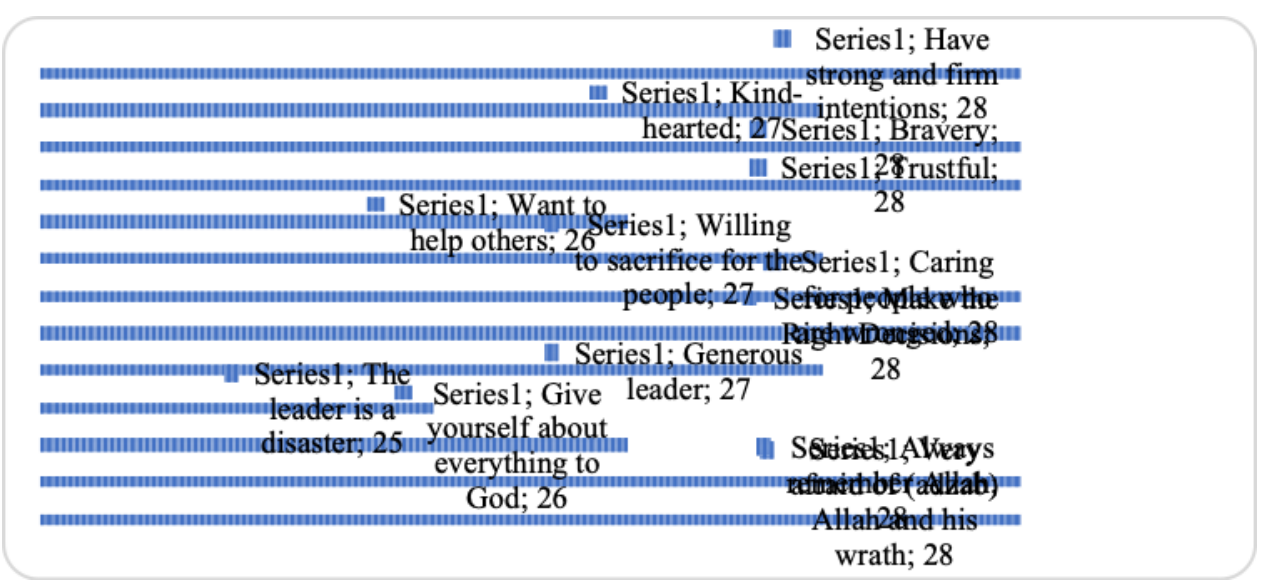

Figure 3: The response of Ibrah Students in the Umayyad Umar bin Abdul Aziz Era

Source: (Data Process Results, 2019)

On the theme of leadership, The leader is a disaster, Generous leader, and Make the Right Decisions. Universal themes are Caring for people who are wronged, Willing to sacrifice for the people, and Want to help others. And on the theme of the nature or example of Umar bin Abdul Aziz namely Trustful, Bravery, Kind-hearted, Have strong and firm intentions.

The mean percentage of student responses on each theme from the highest is, the theme of the nature or example of $99.11 \%$ (27.75), the theme of God by $97.62 \%$ (27.33), social themes of $96.43 \%$ (27), and the theme of Leadership was $95.24 \%$ (26.67). One example of the response from students to the achievements of the Umayyad Dynasty during Umar bin Abdul Aziz is presented in Figure 4.

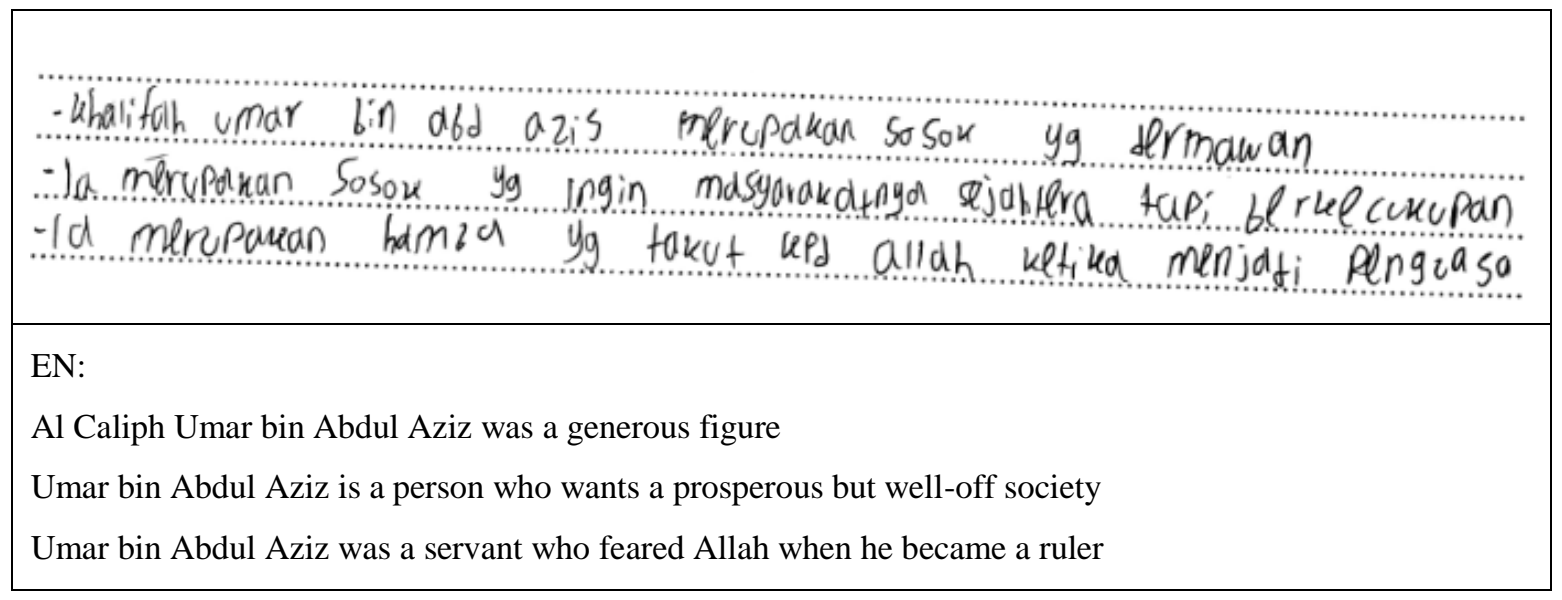

Figure 4: Examples of Lessons Learned By Students

Source: (Data Process Results, 2019)

Based on the answers of students in Figure 4 included in the category that reflects the theme of God, then it is inserted into it, namely in the sentence, "Umar bin Abdul Aziz is a servant who is afraid of God when becoming a ruler". Or the answers of other similar students, for example, "are very afraid of God's punishment and His wrath". So the keywords fear are grouped in the theme of God. Besides, for example, student answers that say, "(Umar bin Abdul Azis) a leader who is obedient to God", or other student answers that state, "(Umar bin Abdul Azis) always remember God", these two student answers are also grouped into the theme of Allah with the key to remember and obey God.

\section{DISCUSSION}

Leadership has a relationship with spirituality. Students can connect command with spirituality that is connected with accountability in the afterlife as a form of a Muslim's faith in God, which is the implementation of monotheism. Learners develop reflections on how to become a leader who can carry out the leadership mandate that is colored by the values of monotheism, which is the spiritual basis of a Muslim. This is in line with what was proposed by Burke (Burke, 2006), regarding leadership and spirituality, which gives the ability of a leader to look into his soul, and people who relate to him, and others who are the effects of leadership. Building relationships with those he dreams of and also other people from.

With reflective thinking, students are also stimulated to express the values of spiritual leadership as suggested by Burgess 
(Burgess, 2012), which in the Islamic perspective, these values are, for example, humble. Avoiding excessive spending and avoid imposing their will on the community, rahima (mercy). Ihsan (goodness, kindness) and all (justice) (Ali, 2009; Faris \& Abdalla, 2017). Social students emphasize their reflection also on relationships with others (people) in the form of social care as one of the spiritual dimensions $(\mathrm{Ng}, 2012)$ in the form of social responsibility (Dasti \& Sitwat, 2014), and this is based on values of transcendence and divinity regarding social care. All are placed within the framework of seeking God's blessing and avoiding the wrath.

Social care in Islam can take the general form called sadaqah in all its tangible and intangible forms, for example, smiles or kind words to others, giving a glass of drinking water or planting trees that provide benefits for animals or people. Social care in the form of Sadaqah/charity is a crucial way to build social justice, where justice is the main character of Islam. This social care in Islamic spirituality is a process of self-purification of despicable morals, to achieve the pleasure of Allah (Khanam, Siddiqi, \& Ahmed, 2013)

According to Siddiqui(Siddiqui, 1997), feeling the presence (guidance) of God is an ethical principle (morals) of Islam, this means transcending feelings toward God, thereby giving birth to positive attitudes that make a person to live it to gain the pleasure of God. Morals are closely related to the qualities of the qualities desired by God, for example, the qualities of compassion, generosity, wisdom, and solidarity. These qualities are transcended from the understanding of the 99 names and attributes of Allah, the Just (A'adil), the Most Gracious (Rahman), the Creator (Khaliq), and the Most Merciful (Rahim), the Wise (Al-Hakim) the Giver (Al-Wahab), where the attributes of God are related to his creatures (Sohani, 2017). In the context of leadership or social relations, for example, these attributes of God can be an inspiration in building quality relationships, because these qualities show the moral discipline and personality qualities of the person concerned. Derivatives of the attributes of God in humans such as being generous, wise, forgiving, caring, honest, able to keep a secret, act decisively, be humble, patient (Ali, 2009).

Islamic spirituality related to monotheism is to acknowledge only one god with all the attributes and asthma and his actions, all aspects are related, connected with God in all aspects of life so that life is in accordance with his commands and get his pleasure. This is the spiritual basis of a Muslim, which is the most basic and the main belief, behavior, and thought. From here, a Muslim will build the principle of accountability and justice not only in the life of this world, but he transcends responsibility and justice to the hereafter (Indrawaty \& Wardayati, 2016).

The theme of God is included in it is the remembrance of Allah, in studies (Hamsyah \& Subandi, 2017), remembering God is one of the techniques to develop spiritually. In this theme of God, there is an element of fear (khauf). As for obedience and surrender to God is the basic character of Islam, where it is a part of one's responsibility regarding spiritual and religious obligations towards God and the responsibility of his moral actions towards fellow beings(Nanji, 2010). This moral action is related to social themes.

The theme of the social community, as the third theme of the findings of this study, is a reflection of students related to spirituality in social issues. For example, about keywords from students, caring for people who are wronged, close to the people, caring, and willing to sacrifice for the people (not personal). All of these can be included in social themes.

The last theme is attributed (traits/traits), keywords that can be grouped in this theme come from students' explanations about the quality of spiritual qualities as a form of God's nature, or qualities that must be avoided because they conflict with spirituality. For example, it is reflected in the students' expressions: having the righteous nature, having a fair nature, being strict in all matters, having strong and firm intentions, being wise in managing state finances, being disciplined when carrying out any task, daring to take difficult decisions, being responsible for the mandate that he can, Being a person who tawadhuk humble not arrogant.

General themes such as the above can be drawn from the results of the students' reflection as their focus in the process of assessing what happened after they watched a video showing about a piece of the story of Umar bin Abdul Aziz as the head of state/caliph of the Umayyad. These themes related to the spiritual are, first, can be drawn from the side of the spiritual meaning, which means the meaning of something that appears on the surface of the phenomenon to find the inner side of what is seen by students. The second in terms of the spiritual dimension of Islam, awareness of the existence of God in living life according to its rules.

Reflecting messages implied by video shows will give students the opportunity to explore further the meaning of what they see, according to(Souza, Francis, Norman, \& Scott, 2009), reflection can play an effective role in strengthening the spiritual development of adolescents (effective in promoting spiritual development in adolescents). In this research, for example, students can build their views on personal conflicts of interest with the interests of society, or it can also be students who are intrigued to reveal messages about their understanding of responsibility. Students examine the religious issue of the relationship between the fear of God's adherence in the hereafter with a social concern or personal determination.

Students are trained to reflect that he will internalize the spiritual into himself. For example, a video showing Umar bin 
Abdul Aziz's concern for his people will provide a challenge for students to reflect on social themes in the form of doing good to society and avoiding selfishness which is spiritually Islamic this can be seen as a form of expression of nature God of mercy to the worlds.

\section{CONCLUSION}

The results of research and discussion show that the impact of learning the history of Islamic culture using video on the spiritual of students is categorized very well, this is based on four main themes, namely the theme of God, leadership, social, and nature. This is based on the average percentage of student responses regarding the achievements of Umar bin Abdul Aziz on each theme from the highest, i.e., the theme of God $98.21 \%$, Social theme $98.21 \%$, exemplary theme $96.53 \%$, and leadership theme $91.07 \%$. While the average percentage of student responses on the ability to pick Ibn from the highest is, the theme of nature or example is $99.11 \%$, the theme of God is $97.62 \%$, the social theme is $96.43 \%$, and the theme of Leadership is $95.24 \%$. Based on these results, video technology has an effective impact on learning, teachers need to have knowledge and skills using video technology, and teachers must be able to design technology-based learning that gives meaning to students, as one of the effective teaching strategies.

\section{LIMITATION AND FORWARD STUDY}

In most religions lessons, especially Islamic subjects taught at school applies conventional or traditional methods where teachers by means of speech dominate the teachers' way of teaching. It is rarely found a new teaching method by making use of teaching media from a technology perspective. This study includes the media in terms of video to transfer knowledge during the instructional process. This results in this research have a major limitation is only applicable to a certain topic within the video. It is suggested for further research to conduct the research by developing the video to be interactive and covers almost all of the topics be included.

\section{ACKNOWLEDGMENT}

Wholeheartedly thankfulness is dedicated to the authors for the real and true contributions from arranging this article from the draft into the final manuscript. Respectful greeting for the first author as setting, arranging, and overviewing the article, second author in data gathering and analyzing, the third author in presenting the data in a graph, tables, and fourth author to have proofreading.

\section{REFERENCES}

1. Ali, A. J. (2009). Islamic perspectives on leadership: a model. International Journal of Islamic and Middle Eastern Finance and Management, 2(2), 160-180. https://doi.org/10.1108/mf.2008.00934jaa.001

2. Arsad, N. M., Osman, K., \& Soh, T. M. T. (2011). Instrument development for 21st-century skills in Biology. Procedia - Social and Behavioral Sciences, 15, 1470-1474. https://doi.org/10.1016/j.sbspro.2011.03.312

3. Bingimals, K. A. (2009). Barriers to the Successful Integration of ICT in Teaching and Learning Environments: A Review of the Literature. Eurasia Journal of Mathematics, Science \& Technology Education, 5(3), 235-245. https://doi.org/10.1108/09578230310464666

4. Buchanan, M. T., \& Hyde, B. (2008). Learning beyond the surface: Engaging the cognitive, affective, and spiritual dimensions within the curriculum. International Journal of Children's Spirituality, 13(4), 309-320. https://doi.org/10.1080/13644360802439458

5. Burgess, D. S. (2012). Spirituality In Leadership: How Male African American Leaders In Higher Education Perceive The Influence Of Spirituality In Their Decision Making. Colorado State University.

6. Burke, R. (2006). Leadership and spirituality. Foresight, 8(6), 14-25. https://doi.org/10.1108/14636680610712504

7. Dasti, R., \& Sitwat, A. (2014). Development of a Multidimensional Measure of Islamic Spirituality (MMS). Journal of Muslim Mental Health, 8(2), 47-67. https://doi.org/10.3998/jmmh.10381607.0008.204

8. Faris, N., \& Abdalla, M. (2017). Leadership in Islam: Thoughts, Processes, and solutions in Australian organizations. In Leadership in Islam: Thoughts, Processes, and Solutions in Australian Organizations. https://doi.org/10.1007/978-3-319-66441-5

9. Fuller, K. H. (1999). Lesson from the screen: Film and Video in the Classroom. Retrieved November 3, 2019, from www.historians.org website: https://www.historians.org/publications-an d-directories/perspective s-on-history /april-1999/lessons-from-the-screen-film- and-video-in-the-classrooom(Accessed on 20 February 2020)

10. Graham, S. (2003). Instructional Design for Affective Learning in Theological Education. British Journal of Theological Education, 14(1), 58-77. https://doi.org/10.1558/jate.v14i1.58

11. Hamsyah, F., \& Subandi. (2017). Dzikir and Happiness: A Mental Health Study on An Indonesian Muslim Sufi Group. Journal of Spirituality in Mental Health, 19(1), 80-94. https://doi.org/10.1080/19349637.2016.1193404

12. Indrawaty, \& Wardayati, S. M. (2016). Implementing Islamic Corporate Governance (ICG) and Islamic Social Reporting (ISR) in Islamic Financial Institution (IFI). Procedia - Social and Behavioral Sciences, 219, 338-343. 
https://doi.org/10.1016/j.sbspro.2016.04.042

13. Kemendikbud, RI. (2017). Panduan Implementasi Kecakapan Abad 21 Kurikulum 2013 di Sekolah Menengah Atas. Jakarta: Direktorat Pembinaan SMA.

14. Khanam, F., Siddiqi, N., \& Ahmed, A. (2013). Social Welfare in Islam: Spirit of Islam.

15. Khine, M. S., \& Fisher, D. (2003). Technology-rich learning environments: A future perspective. In Technology-Rich Learning Environments: A Future Perspective. https://doi.org/10.1142/5325

16. Marcus, A. S., Metzger, S. A., Paxton, R. J., \& Stoddard, J. D. (2018). Teaching History With Film. In The Routledge Companion to Media Education, Copyright, and Fair Use. https://doi.org/10.4324/9781315637549-16

17. Misztal, W., Gurba, K., \& Nęcek, R. (2018). Effectiveness Of Virtual Collaboration In Distance Education From The Perspective Of Spiritual Development. International Conference on Education and New Learning Technologies. Spain. https://doi.org/10.21125/edulearn.2018.1904

18. Mokhtar, S. B. (2017). a Techno-Religious Framework To Scaffold Spiritual Intelligence Among Students. The University of Malaya.

19. Mthembu, T. G., Wegner, L., \& Roman, N. V. (2017). Barriers to Integration of Spirituality and Spiritual Care in Occupational Therapy Education in a South African context. Journal of Spirituality in Mental Health, 19(1), 61-79. https://doi.org/10.1080/19349637.2016.1206843

20. Nanji, A. (2010). Islamic Ethics. Global Religious Vision, 4(1), 78-98. https://doi.org/10.4324/9780203855270

21. Ng, Y. L. (2012). Spiritual development in the classroom: Pupils' and educators' learning reflections. International Journal of Children's Spirituality, $17(2), \quad 167-185$. https://doi.org/10.1080/1364436X.2012.726609

22. O'Siochru, C. (2019). Norton, L. (2019). Action research in learning and teaching: A practical guide to conducting pedagogical research in universities. In Psychology Learning \& Teaching (Vol. 18). https://doi.org/10.1177/1475725719850329

23. Ruismäki, H., Salomaa, R.-L., \& Ruokonen, I. (2015). Minerva Plaza - A New technology-rich Learning Environment. Procedia - Social and Behavioral Sciences, 171, 968-981. https://doi.org/10.1016/j.sbspro.2015.01.216

24. Seifert, T. A., Goodman, K. M., \& Harmon, N. (2009). Methods for Assessing Inner Development: Spirituality andBeyond. Journal of College and Character, 10(7), 3-8. https://doi.org/10.2202/1940-1639.1690

25. Siddiqui, A. (1997). Ethics in Islam: Key concepts and contemporary challenges. Journal of Moral Education, 26(4), 423-431. https://doi.org/10.1080/0305724970260403

26. Soh, T. M. T., Osman, K., \& Arsad, N. M. (2012). M-21CSI: A validated 21st-century skills instrument for secondary science students. Asian Social Science, 8(16), 38-44. https://doi.org/10.5539/ass.v8n16p38

27. Sohani, A. (2017). The intellectual, ethical, and, spiritual dimensions of the Islamic thought.

28. Souza, M. de, Francis, L. J., Norman, J. O., \& Scott, D. (2009). International Handbook of Educational for Spirituality, Care, and Wellbeing. New York: Springer. https://doi.org/10.1007/978-1-4020-9018-9

29. Spyker, S. K. (2007). Technology \& Spirituality: How the Information Revolution Affects Our Spiritual Lives. Woodstock, Vernont: SkyLight Paths Publishing.

30. Teuten, E. L., Saquing, J. M., Knappe, D. R. U., Barlaz, M. A., Jonsson, S., Björn, A., ... Takada, H. (2009). Transport and release of chemicals from plastics to the environment and wildlife. Philosophical Transactions of the Royal Society B: Biological Sciences, 364(1526), 2027-2045. https://doi.org/10.1098/rstb.2008.0284

31. Tsur, M. (2014). Research Confirms Video Improves Learning Results. Retrieved from www.huffpost.com website: https://www.huffpost.com/entry/research-confirms-video-i_b_5064181 